\title{
UTILIZATION OF WATER HYACINTH PLANTS (EICHORNIA CRASSIPES), JASMINE WATER (ECHINODORUS PALEAFOLIUS) AND APU WOOD (PISTIASTRATIOTES) ON DECREASING LEVEL OF LIQUID WASTE POISONOUS OF TOFU
}

\author{
Wiznie Fadhillah ${ }^{1 *}$, Edison Purba ${ }^{2}$, Deni Elfiati ${ }^{2}$ \\ ${ }^{1}$ Post graduate of Agrotechnology, Agriculture Faculty, University of North Sumatra, Medan, Indonesia \\ ${ }^{2}$ Agrotechnology Department, Agriculture Faculty, University of North Sumatra, Medan, Indonesia \\ "Corresponding author: wizniefadhillah@gmail.com
}

\begin{abstract}
The aim of this research was to improve the quality of liquid waste water by looked at the role of test plants (warter hyacinth, water jasmine and apu wood)by phytoremediation process in reducing pollutant level. This research was conducted at Rumah Kaca Faculty of Agriculture University of Sumatera Utara Medan from July 2016 to April 2017.This research was used factorial randomized block design with two factors. The first factor was tofu waste with three levels; LO (no waste) as control , L1(25\%) and L2 (50\%). The second factor was plant species with four levels were T0 (no plant as control), T1 (water hyacinth), T2 (jasmine water) and T3 (apu wood). The parameters observed were BOD $(\mathrm{mg} / \mathrm{L})$, COD $(\mathrm{mg} / \mathrm{L})$, TSS $(\mathrm{mg} / \mathrm{L}), \mathrm{NH}_{3} \mathrm{~N}(\mathrm{mg} / \mathrm{L}), \mathrm{pH}$, waste colours, odor waste and dry weight of plans (grams).The results showed that the three test plants could be used for phytoremediation process, tofu waste, $25 \%$ waste concentration as the best apu wood in reducing the pollutant level of tofu waste.
\end{abstract}

Keywords: tofu liquid waste, aquatic plants, phytoremediation, contaminants

\section{INTRODUCTION}

The environmental pollution produced by the tofu industry is a viscous liquid separated from a clump of so-called whey that contains suspended or dissolved solids, undergoes physical, chemical, and biological changes that will produce toxic substances or create a medium for growth of germs (Asmadi et al., 2012).

The waste will turn its color into dark brown and foul-smelling. This stench will cause respiratory distress. If this waste goes to the river it will pollute the river and if it is still used it will cause itching, diarrhea, and nausea (Archer et al.,2004).It has now found a new, cheaper, economical and environmentally friendly way of processing waste that is phytoremediation. Phytoremediation is the use of green plants, especially aquatic plants such as water hyacinth, lotus, etc. in cooperation with microbiota, enzymes, water consumption, soil changes, and agronomic techniques to eliminate, load or neutralize harmful contaminants from the environment such as heavy metals, pesticides , xenobiotic, organic compounds, toxic aromatic pollutants, acidic mining drainage (Asmadi et al., 2012; Dordio et al., 2011; Newman et al., 2004; Ratnani, 2012; Rido et al., 2010).

Water hyacinth (Eichornia crassipes) was very sensitive to nutrient conditions is insufficient but the response to high nutrient concentrations (Cook, 1996), water jasmine (Echinodorus paleafolius) has the ability to neutralize certain components in the water, and it is very useful in liquid waste processing (Asmadi et al., 2012). has the general ability to neutralize certain components in the waters, and it is very useful in the processing of liquid waste (Asmadi et al., 2012). and wood apu (Pistia stratiotes) selected because it is easy to obtain and cultivated, can live in an environment with stagnant water, has the ability to reduce the contaminant content in waste water up to $90 \%$ (Ratnani, 2012). Besides, it can reduce the heavy metal content of Cd by 96.73\% (Asmadi et al., 2012). COD percentage decrease of $64.7 \%$ (Asmadi et al., 2012). The aim of this research was to improve the quality of liquid waste water by looked at the role of test plants (warter hyacinth, water jasmine and apu wood) by phytoremediation process in reducing pollutant level

\section{MATERIALS AND METHOD}

This research was conducted at Rumah Kaca Faculty of Agriculture University of Sumatera Utara Medan, Balai Lingkungan Hidup Laboratory from July 2016 to April 2017.This research was used factorial randomized block design with two factors and three replications. The first factor was tofu waste with three levels; L0 (no waste) as control , $\mathrm{L} 1(25 \%)$ and $\mathrm{L} 2(50 \%)$. The second factor was plant species with four levels were T0 (no plant as control), T1 (water hyacinth), T2 (jasmine water) and T3 (apu wood). 
Tofu wastewater samples were taken from the industry Bunga Asoka street gang Restu as much as 350 liters. Water hyacinth from pasar dua Tanjunga Sari Medan, jasmine water from pasar enam Medan and apu wood from the library field in University of Sumatera Utara Medan. Acclimatization of plants for 14 days in 12 liters of clean water.36 bucket filled with wastewater tofu according to treatment and in planting with 6 plants bucket

The parameters observed were BOD (mg / L), COD (mg / L), TSS (mg / L), $\mathrm{NH}_{3} \mathrm{~N}$ (mg / L), pH, waste colours, odor waste and dry weight of plans (grams). Waste analysis has done four times, day 0, 5, 15 and 30 days after planting. The data were analyzed statistically based on variance analysis on each observed variables measured evidently continued by using Duncan Multiple Range Test at $5 \%$ level.

\section{RESULTS AND DISCUSSION}

\subsection{Quality of Wastewater to Know Before Phytoremediation}

The quality of liquid waste know before phytoremediation it is necessary for initial measurement to know the characteristics of the liquid waste used when the research. The knowable liquid waste used in this study has an initial quality as in Table1. Based on the results of the parameter test of Table 1, the tofu wastewater is not feasible to be discharged directly to the environment, levels of BOD, COD, TSS, NH3-N and pH of waste have exceeded the quality standards allowed under Regulation of Minister of Environment No. 5, 2014.

Table1. Quality of Tofu Liquid Waste

\begin{tabular}{|c|c|c|c|c|}
\hline \multirow{2}{*}{$\begin{array}{l}\text { No. } \\
1 .\end{array}$} & Parameter & \multicolumn{3}{|c|}{ analysis results*quality standards } \\
\hline & BOD $100 \%$ & $\mathrm{mg} / \mathrm{L}$ & 4446 & 150 \\
\hline & BOD $50 \%$ & $\mathrm{mg} / \mathrm{L}$ & 948 & 150 \\
\hline & BOD $25 \%$ & $\mathrm{mg} / \mathrm{L}$ & 541 & 150 \\
\hline \multirow[t]{3}{*}{2.} & COD $100 \%$ & $\mathrm{mg} / \mathrm{L}$ & 8390 & 300 \\
\hline & COD $50 \%$ & $\mathrm{mg} / \mathrm{L}$ & 1790 & 300 \\
\hline & COD $25 \%$ & $\mathrm{mg} / \mathrm{L}$ & 1040 & 300 \\
\hline \multirow[t]{3}{*}{3.} & TSS $100 \%$ & $\mathrm{mg} / \mathrm{L}$ & 866 & 200 \\
\hline & TSS $50 \%$ & $\mathrm{mg} / \mathrm{L}$ & 768 & 200 \\
\hline & TSS $25 \%$ & $\mathrm{mg} / \mathrm{L}$ & 574 & 200 \\
\hline \multirow[t]{3}{*}{4.} & $\mathrm{NH}_{3} \mathrm{~N} 100 \%$ & $\mathrm{mg} / \mathrm{L}$ & 21.1 & 5 \\
\hline & $\mathrm{NH}_{3} \mathrm{~N} 50 \%$ & $\mathrm{mg} / \mathrm{L}$ & 6,20 & 5 \\
\hline & $\mathrm{NH}_{3} \mathrm{~N} 25 \%$ & $\mathrm{mg} / \mathrm{L}$ & 1,60 & 5 \\
\hline \multirow[t]{3}{*}{5 . } & $\mathrm{pH}$ & & 4.25 & $6-9$ \\
\hline & $\mathrm{pH} \quad 50 \%$ & & 4.86 & $6-9$ \\
\hline & $\mathrm{pH} \quad 25 \%$ & & 5.20 & $6-9$ \\
\hline
\end{tabular}

*Source: Minister of Environment Regulation No. 5 of 2014 Quality Wastewater Tofu After Phytoremediation

\subsection{BOD (Biological Oxygent Demand) mg/L}

The results of the analysis test showed thatphytoremediation process with the three test plants (water hyacinth, water jasmine and apu wood) gave a significant effect in decreasing BOD (mg / L) of tofu waste.

Table 2. Results of Duncan Multiple Test Analysis BOD (mg / L)

\begin{tabular}{cccccc}
\hline \multirow{2}{*}{ Days } & Treatment & $\begin{array}{c}\mathrm{L} 0 \\
(\mathrm{mg} / \mathrm{L})\end{array}$ & $\begin{array}{c}\mathrm{L} 1 \\
(\mathrm{mg} / \mathrm{L})\end{array}$ & $\begin{array}{c}\mathrm{L} 2 \\
(\mathrm{mg} / \mathrm{L})\end{array}$ & Average \\
\hline \multirow{4}{*}{5} & T0 & $5,88 \mathrm{c}$ & $541,00 \mathrm{~b}$ & $317,00 \mathrm{a}$ & 178,06 \\
& T1 & $5,84 \mathrm{c}$ & $211,33 \mathrm{~b}$ & $155,33 \mathrm{c}$ & 69,90 \\
& T2 & $5,87 \mathrm{c}$ & $48,50 \mathrm{~d}$ & $300,33 \mathrm{a}$ & 126,21 \\
& T2 & $5,83 \mathrm{c}$ & $72,47 \mathrm{c}$ & $174,00 \mathrm{c}$ & 80,86 \\
& Average & 5,85 & 98,77 & 236,67 & \\
& T0 & $5,88 \mathrm{~d}$ & $142,00 \mathrm{~b}$ & $301,67 \mathrm{a}$ & 178,06 \\
& T1 & $5,84 \mathrm{~d}$ & $51,73 \mathrm{c}$ & $67,83 \mathrm{c}$ & 69,90 \\
& T2 & $5,84 \mathrm{~d}$ & $65,30 \mathrm{c}$ & $56,50 \mathrm{c}$ & 126,21 \\
& T3 & $5,80 \mathrm{~d}$ & $69,40 \mathrm{c}$ & $67,30 \mathrm{c}$ & 80,86 \\
& Average & 5,84 & 82,11 & 123,33 & \\
& T0 & $5,85 \mathrm{c}$ & $255,00 \mathrm{a}$ & $286,33 \mathrm{a}$ & 182,39 \\
& T1 & $5,82 \mathrm{c}$ & $29,40 \mathrm{c}$ & $75,33 \mathrm{bc}$ & 36,85 \\
& T2 & $5,85 \mathrm{c}$ & $39,43 \mathrm{c}$ & $102,87 \mathrm{~b}$ & 49,38 \\
& T3 & $5,81 \mathrm{c}$ & $27,87 \mathrm{c}$ & $53,63 \mathrm{c}$ & 21,33 \\
\hline
\end{tabular}




Average $\quad 5,83 \quad 87,93 \quad 129,54$

Explanation : The numbers in unequal columns followed by unequal notation show significant differences according to Duncan Multiple Range Test at $5 \%$ level

Table 1 showed that water hyacinthhigher to lower BOD (mg/l) content followed by water hyacinth and water jasmine. Based on the research, the three test plants gave satisfactory results as phytoremediation agent able to decrease $\mathrm{BOD}(\mathrm{mg} / \mathrm{l})$ in good category $(\leq 150)$ at $25 \%$ waste concentration and $50 \%$ waste concentration. The highest decrease of phytoremediation occurred in the apu wood test plant on $30^{\text {th }}$ day $(27.87) 94.85 \%$ followed by water hyacinth (29.4) $94.6 \%$ and water jasmine (39.43) $92.71 \%$.

The influence of the residence time contributes to the phytoremediation process of decreasing the waste content (Fachrurozi, et al., 2010). decreasing the BOD (mg / L) level by apu wood due to apu wood having a good role in supporting the absorption rate of existing nutrients, the activity of microorganisms with the plants, through the process of oxidation of aerobic bacteria which grows around the plant's rhizosphere. Plant roots increase the density and microbial activity provided by the root surface for microbial growth (Fachrurozi, et al., 2010). According to (Fachrurozi, et al., 2010) the occurrence of microbiological activity at the roots, oxygen in the roots is fulfilled then the microorganisms that play a role describing the waste is also getting bigger.

\subsection{Chemical Oxygen Demand (COD)}

The result of analysis of COD ( $\mathrm{mg} / \mathrm{L}$ ) can be seen that the effect of waste concentration and plant type has significant effect, the interaction between the concentration of waste treatment and the type of test plant has significant effect on the level of COD (mg/l) of tofu waste.

Table 3. Results of Duncan Multiple Test Analysis COD(mg / L)

\begin{tabular}{rcrlrrr}
\hline Days & Treatment & L0 & L1 & L2 & Average \\
\hline \multirow{4}{*}{5} & T0 & 11,67 & $\mathrm{~g}$ & $305,33 \mathrm{c}$ & $314,33 \mathrm{~b}$ & 210,44 \\
& T1 & $12,00 \mathrm{~g}$ & $99,33 \mathrm{f}$ & $274,33 \mathrm{e}$ & 128,56 \\
& T2 & $11,67 \mathrm{~g}$ & $103,33 \mathrm{f}$ & $393,67 \mathrm{a}$ & 168,89 \\
& T3 & 11,67 & $\mathrm{~g}$ & $100,00 \mathrm{f}$ & $296,67 \mathrm{~d}$ & 121,11 \\
& Average & 11,75 & & 151,50 & 313,00 & \\
& T0 & $11,33 \mathrm{i}$ & $306,00 \mathrm{~b}$ & $352,00 \mathrm{a}$ & 223,11 \\
& T1 & $11,67 \mathrm{i}$ & $90,67 \mathrm{~g}$ & $131,33 \mathrm{c}$ & 77,89 \\
& T2 & $12,00 \mathrm{i}$ & $104,33 \mathrm{e}$ & $111,33 \mathrm{~d}$ & 75,89 \\
& T3 & 11,67 & $\mathrm{i}$ & $85,67 \mathrm{~h}$ & $96,33 \mathrm{f}$ & 64,56 \\
& Average & 11,67 & & 146,67 & 172,75 & \\
& T0 & 12,67 & $\mathrm{~h}$ & $330,33 \mathrm{~b}$ & $657,00 \mathrm{a}$ & 333,33 \\
& T1 & $12,33 \mathrm{~h}$ & $61,00 \mathrm{f}$ & $150,00 \mathrm{~d}$ & 74,44 \\
& T2 & 12,67 & $\mathrm{~h}$ & $72,50 \mathrm{e}$ & $198,33 \mathrm{c}$ & 94,50 \\
& T3 & 11,00 & $\mathrm{~h}$ & $50,00 \mathrm{~g}$ & $63,67 \mathrm{f}$ & 41,56
\end{tabular}

Note: The numbers in unequal columns followed by unequal notation show significant differences according to Duncan Multiple Range Test at $5 \%$ level

The result of analysis test showed that levels of COD $(\mathrm{mg} / \mathrm{L})$ at the lowest $25 \%$ and $50 \%$ concentrations in the apu wood test plant were $50.00 \mathrm{mg} / \mathrm{L}$ and $63.67 \mathrm{mg} / \mathrm{L}(95.19 \%$ and $96.44 \%)$, followed by water hyacinth test plant of $61.00 \mathrm{mg} / \mathrm{L}$ and $150.00 \mathrm{mg} / \mathrm{L}(94.14 \%$ and 91.62\%) and water jasmine test plant of $72.50 \mathrm{mg} / \mathrm{L}$ and $198.33 \mathrm{mg} /$ $\mathrm{L}(93.03 \%$ and $88.92 \%)$.

The duration of stay in the bucket could be the cause of the decrease in COD, the higher of degraded microbes (Fachrurozi, et al., 2010), contained of organic matter in the waste water was converted by microorganisms into simpler compounds and will be utilized by plants as nutrients, where the wood apu root system produces oxygen that was used energy catalyst for metabolic processes for the life of microorganisms (Fachrurozi, et al., 2010).

\subsection{TSS (Total Suspended Solid)}

The results of the analysis of variance showed that the interaction between the treatment of waste and the type of test crops had significant effect on the level of TSS (mg / L) of the tofu waste on the 15th day. The effect of the concentration of waste and the type of test crop significantly affected the value TSS (mg / L) of tofu liquid waste. 
Tabel 4. Data Analysis Using Duncan Multiple Test TSS (mg / L)

\begin{tabular}{clcccr}
\hline \multirow{2}{*}{ Days } & Treatment & $\begin{array}{c}\text { L0 } \\
(\mathrm{mg} / \mathrm{L})\end{array}$ & $\begin{array}{c}\mathrm{L} 1 \\
(\mathrm{mg} / \mathrm{L})\end{array}$ & $\begin{array}{c}\text { L2 } \\
(\mathrm{mg} ? \mathrm{~L})\end{array}$ & Average \\
\hline \multirow{5}{*}{5} & T0 & 0,00 & 46,00 & 150,33 & 65,44 \\
& T1 & 0,00 & 67,67 & 129,00 & 65,56 \\
& T2 & 0,00 & 49,00 & 201,67 & 83,56 \\
& T3 & 0,00 & 57,67 & 154,67 & 70,78 \\
& Average & $0,00 \mathrm{c}$ & $55,08 \mathrm{~b}$ & $158,92 \mathrm{a}$ & \\
& T0 & $0,00 \mathrm{~g}$ & $128,00 \mathrm{~b}$ & $196,67 \mathrm{a}$ & $108.22 \mathrm{a}$ \\
& T1 & $0,00 \mathrm{~g}$ & $8,00 \mathrm{~g}$ & $74,00 \mathrm{~d}$ & $26.67 \mathrm{c}$ \\
& T2 & $0,00 \mathrm{~g}$ & $21,00 \mathrm{f}$ & $116,00 \mathrm{c}$ & $45,67 \mathrm{~b}$ \\
& T3 & $0,00 \mathrm{~g}$ & $6,00 \mathrm{~g}$ & $34,00 \mathrm{e}$ & $13,30 \mathrm{~d}$ \\
& Average & 0,00 & 40,75 & 105,17 & \\
& T0 & $0,00 \mathrm{~h}$ & $205,67 \mathrm{~b}$ & $322,33 \mathrm{a}$ & 333,33 \\
& T1 & $0,00 \mathrm{~h}$ & $34,33 \mathrm{f}$ & $55,67 \mathrm{~d}$ & 74,44 \\
& T2 & $0,00 \mathrm{~h}$ & $31,00 \mathrm{f}$ & $63,67 \mathrm{c}$ & 94,50 \\
& T3 & $0,00 \mathrm{~h}$ & $13,67 \mathrm{~g}$ & $40,00 \mathrm{e}$ & 41,56 \\
& Average & $0,00 \mathrm{c}$ & $71,17 \mathrm{~b}$ & $120,42 \mathrm{a}$ & \\
\hline
\end{tabular}

Note: The numbers in unequal columns followed by unequal notation show significant differences according to Duncan Multiple Range Test at $5 \%$ level

The lowest level of TSS (mg / L) was present on the 15th day of the wood apu plant treatment at a $25 \%$ waste concentration of $6.00 \mathrm{mg} / \mathrm{L}$ percent reduction of TSS (mg / L) level of $97.9 \%$ and highest in treatment without plant (control) at a concentration of $50 \%$ waste of $768 \mathrm{mg} / \mathrm{L}$ with a percentage reduction of TSS (mg / L) by $58 \%$.

The percentage rate of TSS (mg / L) decrease in control by 58\% is due to the precipitation gravity alone[5]. Environmental factors affect the levels of TSS ( $\mathrm{mg} / \mathrm{L})$ as the entry of flies to planting media and moss plants that develop in the media. The mass of moss and animal plants increases the mass of suspended substances so that the value of TSS (mg / L) rises [9], this causes the TSS value that has dropped on the 5th day back up to the 30th day in the bucket. The highest percentage reduction of TSS ( $\mathrm{mg} / \mathrm{L}$ ) content by $97.6 \%$ by the apu wood test crop is due to the fact that the apu wood test crop has many fiber roots so that, the more places the colloidal attachment hovers in the water at the roots (Newman et al., 2004; Padmaningrum et al., 2014; Primayekti, 2011).

The decrease in TSS (mg / L) may be due to the ability to grow greatly depending on the nutrient content in the waste. the condition of the plant in a small bucket there is dead and damaged. This is thought to be related to the process of adaptation of apu wood with newly grown environments with different nutrient content from their original environment (Novianto, 2012).

\section{5. $\mathrm{NH}_{3} \mathrm{~N}$ (Amonia Total)}

The result of variance analysis showed that the effect of concentration, type of test plant and the interaction between the concentration of waste and the type of plant test had significant effect on $\mathrm{NH}_{3}-\mathrm{N}(\mathrm{mg} / \mathrm{L})$.

Tabel 5. Data Analysis Using Duncan Multiple Test $\mathrm{NH}_{3} \mathrm{~N}$ (mg / L)

\begin{tabular}{rccrrr}
\hline Days & Treatment & L0 & L1 & L2 & Average \\
\hline \multirow{4}{*}{5} & T0 & $0,00 \mathrm{c}$ & $50,00 \mathrm{c}$ & $50,00 \mathrm{c}$ & $35,00 \mathrm{~b}$ \\
& T1 & $0,00 \mathrm{c}$ & $10,40 \mathrm{de}$ & $70,00 \mathrm{~b}$ & $26,80 \mathrm{c}$ \\
& T2 & $0,00 \mathrm{c}$ & $11,27 \mathrm{~d}$ & $89,00 \mathrm{a}$ & $33,42 \mathrm{~b}$ \\
& T3 & $0,00 \mathrm{c}$ & $45,17 \mathrm{c}$ & $77,67 \mathrm{~b}$ & $40,94 \mathrm{a}$ \\
& Average & $0,00 \mathrm{c}$ & $29,10 \mathrm{~b}$ & $72,92 \mathrm{a}$ & \\
& T0 & $0,00 \mathrm{c}$ & $10,20 \mathrm{c}$ & $16,37 \mathrm{a}$ & $8,86 \mathrm{a}$ \\
& T1 & $0,00 \mathrm{c}$ & $1,02 \mathrm{e}$ & $11,40 \mathrm{~b}$ & $4,14 \mathrm{~b}$ \\
& T2 & $0,00 \mathrm{c}$ & $0,06 \mathrm{f}$ & $10,53 \mathrm{~b}$ & $3,53 \mathrm{c}$ \\
& T3 & $0,00 \mathrm{c}$ & $0,12 \mathrm{f}$ & $0,18 \mathrm{c}$ & $0,01 \mathrm{~d}$ \\
& Average & $0,00 \mathrm{c}$ & $2,85 \mathrm{~b}$ & $10,83 \mathrm{a}$ & \\
& T0 & $0,00 \mathrm{~g}$ & $66,00 \mathrm{a}$ & $55,33 \mathrm{~b}$ & $40,44 \mathrm{a}$ \\
& T1 & $0,00 \mathrm{~g}$ & $3,13 \mathrm{e}$ & $6,67 \mathrm{~d}$ & $3,60 \mathrm{c}$ \\
& T2 & $0,00 \mathrm{~g}$ & $2,34 \mathrm{ef}$ & $22,30 \mathrm{c}$ & $8,21 \mathrm{~b}$ \\
& T3 & $0,00 \mathrm{~g}$ & $1,20 \mathrm{fg}$ & $7,67 \mathrm{~d}$ & $1,77 \mathrm{~d}$ \\
\hline
\end{tabular}

Note: The numbers in unequal columns followed by unequal notation show significant differences according to Duncan Multiple Range Test at $5 \%$ level 
The three plants effectively decreased levels of $\mathrm{NH}_{3}-\mathrm{N}(\mathrm{mg} / \mathrm{L})$, the lowest decrease in $\mathrm{NH}_{3} \mathrm{~N}$ levels by jasmine water on day 15 days after planting at $25 \%$ concentration of $0.06 \mathrm{mg} / \mathrm{L}(31.6 \%)$.

The decrease in $\mathrm{NH}_{3} \mathrm{~N}$ levels is due to the decrease in dissolved oxygen levels in the water thereby decreasing the level of life of animals and aquatic plants, the occurrence of ammonification and nitrification. Because in $\mathrm{N}$ waters are in organic form while plants need $\mathrm{N}$ in inorganic form for their minerals needs. Then $\mathrm{N}$ in organic form will be converted into ammonium or ammonia through amonification process in phytoremediation process of water jasmine plant is amonification and nitrification. Because in $\mathrm{N}$ waters are in organic form while plants need $\mathrm{N}$ in inorganic form for their minerals needs. $\mathrm{N}$ as organic form will be converted to ammonium or ammonia through the amonification process (Syarfi et al., 2011).

\section{6. pH (Acidity Level)}

The results of the analysis test showed that the height ofpH significantly different, the largest $\mathrm{pH}$ on day-30 was jasmine water percentage increase of $72.6 \% \mathrm{pH}$ wastewater that was originally acid changed into base. (4.25 - 8 , 39)

Tabel 6. Data Analysis Duncan Using Multiple Test pH

\begin{tabular}{|c|c|c|c|c|c|c|c|c|}
\hline Days & Treatment & LO & & L1 & & L2 & & Average \\
\hline \multirow{4}{*}{5} & T0 & 7,20 & $\mathrm{a}$ & 5,20 & $d$ & 5,60 & $d$ & $5,47 \mathrm{~b}$ \\
\hline & $\mathrm{T} 1$ & 7,20 & $\mathrm{a}$ & 6,19 & $\mathrm{c}$ & 6,30 & bc & $6,56 \mathrm{a}$ \\
\hline & $\mathrm{T} 2$ & 7,19 & $\mathrm{a}$ & 6,60 & $\mathrm{~b}$ & 6,15 & $\mathrm{c}$ & $6,65 \mathrm{a}$ \\
\hline & $\mathrm{T} 3$ & 7,20 & $\mathrm{a}$ & 6,50 & bc & 6,31 & $\mathrm{bc}$ & $6,67 \mathrm{a}$ \\
\hline & Average & $7,20 \quad a$ & & 6,20 & b & $6,09 b$ & & \\
\hline \multirow{4}{*}{15} & T0 & 6,40 & $\mathrm{e}$ & 7,22 & $a b c$ & 6,89 & $\mathrm{~d}$ & 6,84 \\
\hline & T1 & 7,34 & a & 7,18 & abcd & 7,02 & bcd & 7,18 \\
\hline & $\mathrm{T} 2$ & 7,21 & $\mathrm{ad}$ & 7,29 & $a b$ & 7,00 & bcd & 7,17 \\
\hline & $\mathrm{T} 3$ & 7,17 & $\mathrm{ad}$ & 7,13 & abcd & 6,93 & $\mathrm{~cd}$ & 7,08 \\
\hline \multirow{6}{*}{30} & Average & $7,03 \mathrm{~b}$ & & 7,21 & $\mathrm{a}$ & $6,96 \quad b$ & & \\
\hline & T0 & 7,61 & & 8,34 & & 8,06 & & 8,00 \\
\hline & $\mathrm{T} 1$ & 7,87 & & 7,99 & & 8,17 & & 8,01 \\
\hline & $\mathrm{T} 2$ & 7,80 & & 8,01 & & 8,39 & & 8,06 \\
\hline & $\mathrm{T} 3$ & 7,89 & & 8,12 & & 8,24 & & 8,08 \\
\hline & Average & 7,79 & $\mathrm{~b}$ & 8,11 & $\mathrm{a}$ & 8,21 & $\mathrm{a}$ & \\
\hline
\end{tabular}

Note: The numbers in unequal columns followed by unequal notation show significant differences according to Duncan Multiple Range Test at $5 \%$ level

This change in $\mathrm{pH}$ value indicates the activity of microorganisms that degrade organic materials such as proteins and organic nitrogen into ammonium (NH4) which can raise $\mathrm{pH}$ into alkaline (Padmaningrum et al., 2014). For better phytoacumulation, the $\mathrm{pH}$ needs to be conditioned in $\mathrm{pH}$ at neutral atmosphere (Fachrurozi et al., 2010). A good pH condition is a $\mathrm{pH}$ condition that allows biological life in water to run well (Singh et al., 2003). The $\mathrm{pH}$ value is important because it affects the process and the rate of chemical reaction in water $[\mathrm{K}]$. Waste water with $\mathrm{pH}$ is not neutral will complicate the biological process.

\subsection{Color Waste Water Tofu}

Observation data change the color of liquid waste tofu (Table 7) day 0, day 5, day 15 and day 30 after planting. The color change of the waste from the turbid yellow turns brownish, light brown, greenish brown, yellowish green, dark green to dark green. Changes in the color of the waste may be due to the presence of plankton, algae, moss, humus and other organic materials.

The color visually (Table 7) is directly compared to the standard color (clean water). Water with a low turbidity value has a visible color value and the actual color is the same as the standard.

The observed color changes (Table 7) ranging from yellow cloudy ( 0 days after transplanting) turned to white turbidity, brownish yellow, turbid yellow, greenish brown (30 days after planting).

After 30 days, all three treatments showed relatively similar results, which can clear or stabilize the color of the water. From the color observation data of the wastes on the treatment (Table 8), noticeable discoloration of all test plant treatments and the decreasing of waste parameters, proving that the three test plants deserve to be used for treating the tofu liquid waste. Water hyacinth, water jasmine and apu wood can be used as biofilter for organic wastes (Padmaningrum et al., 2014). 


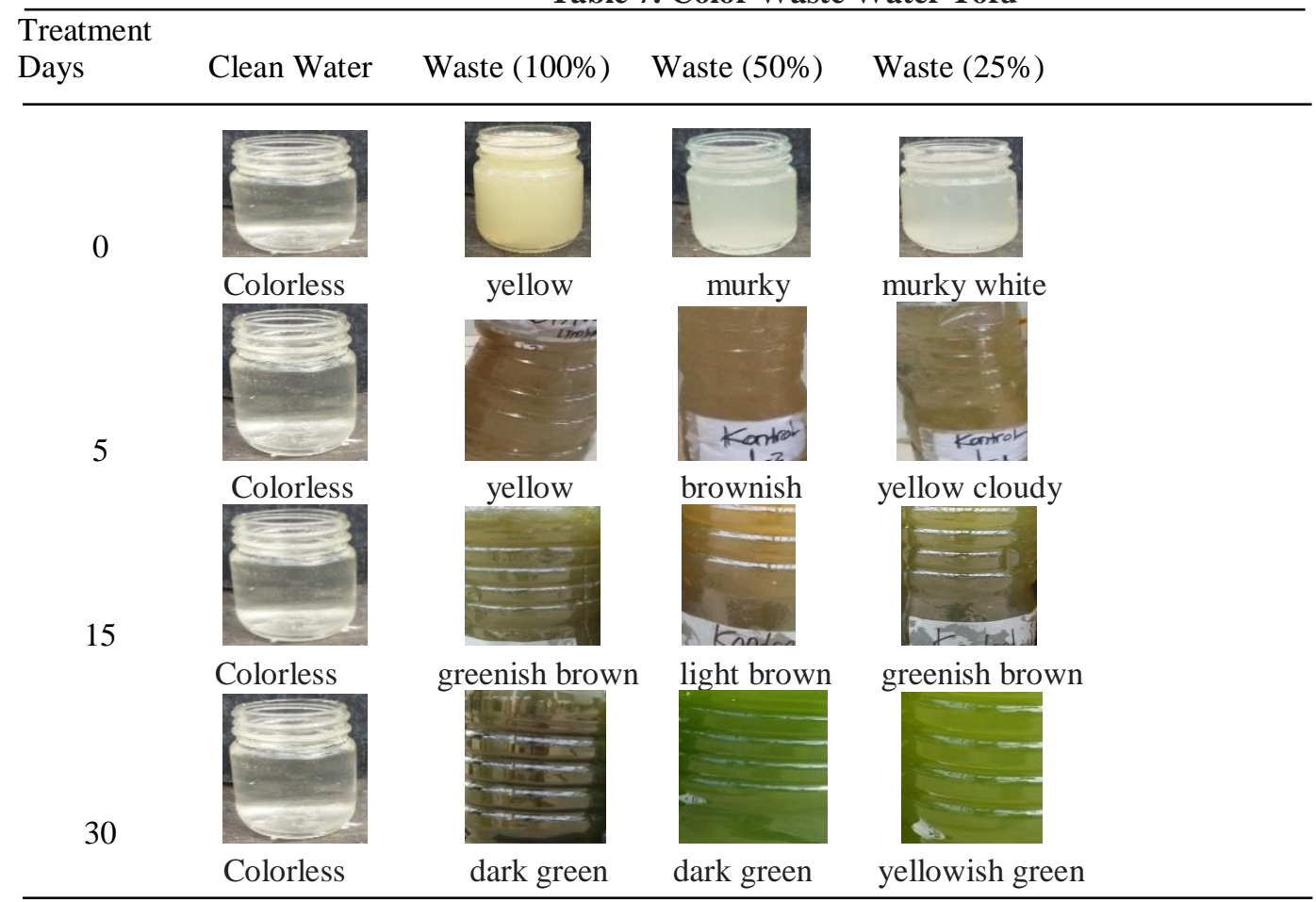

Table 8. Data of Color Changes of Liquid Waste Tofu

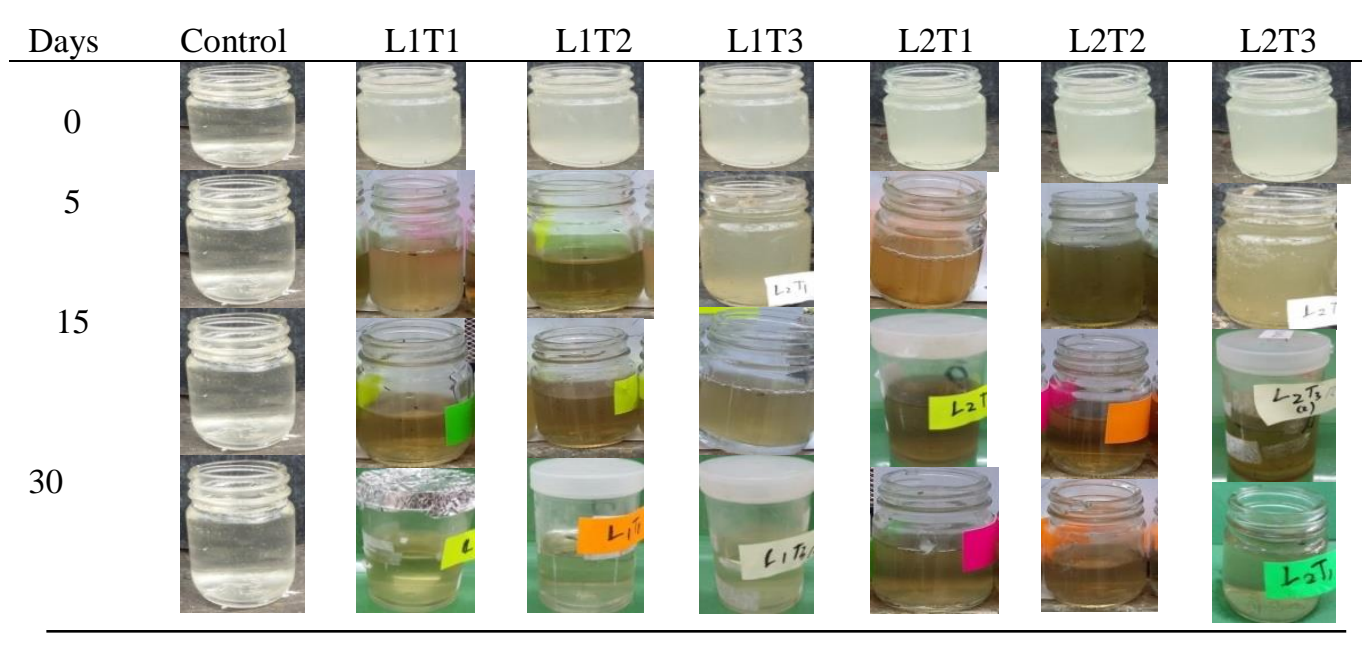

\subsection{Odor Waste of Tofu}

Data from the observation odor waste of tofu liquid waste (Table9), odor changes have occurred on the 5th day after planting (very sting to be quite sting and sting). The odor change from this research is quite successful because on the 15th day, only the treatment of tofu waste concentration $50 \%$ with water hyacinth and water jasmine alone are still slightly smelly. Treatment of $25 \%$ concentration of waste with all three test plants and waste concentration $50 \%$ with the apu wood test plant is no smell or smell of tofu waste lost 
Table 9. Observation of Liquid Waste Odor

\begin{tabular}{|c|c|c|c|}
\hline Days & Treatment & Early Odor & Final Odor \\
\hline 0 & & very stinging & \\
\hline \multirow[t]{6}{*}{5} & L1T1 & & quite stinging \\
\hline & L1T2 & & quite stinging \\
\hline & L1T3 & & quite stinging \\
\hline & L2T1 & & quite stinging \\
\hline & L2T2 & & sting \\
\hline & L2T3 & & sting \\
\hline \multirow[t]{6}{*}{15} & L1T1 & & no smell \\
\hline & L1T2 & & no smell \\
\hline & L1T3 & & no smell \\
\hline & L2T1 & & slightly smelly \\
\hline & L2T2 & & slightly smelly \\
\hline & L2T3 & & no smell \\
\hline \multirow[t]{6}{*}{30} & L1T1 & & no smell \\
\hline & L1T2 & & no smell \\
\hline & L1T3 & & no smell \\
\hline & L2T1 & & no smell \\
\hline & L2T2 & & no smell \\
\hline & L2T3 & & no smell \\
\hline
\end{tabular}

Changes in waste odor from observations (Table 9), indicating that unprocessed waste is getting smelly. The odor that arises due to the breakdown of proteins that produce ammonia and $\mathrm{H}_{2} \mathrm{~S}$ by natural microorganisms. In this study, the odor loss may be due to Ammonia and $\mathrm{H}_{2} \mathrm{~S}$ being absorbed by all three test plants (water hyacinth, jasmine water and apu wood) (Fachrurozi et al., 2010).

\subsection{Plant Biomass}

Observed the growth of the three test plants (Table 10), the increase of dry weight of the three test plants increased, the growth of the three test plants was better at $25 \%$ waste concentration compared with $50 \%$ waste concentration.

The increase in dry weight is thought to be due to plant roots being able to absorb nutrient-rich organic matter in tofu waste and store it into plant vascular tissues for metabolic processes and used to multiply cells and utilized as nutrients needed to support the growth of aquatic plants (Padmaningrum et al., 2014).Nutrient elements available to plants are one of the factors that support plant physiological activities (Sing et al., 2003).

Tabel10. Data of Addition of Dry Weed (gram) of Plant

\begin{tabular}{|c|c|c|c|}
\hline \multirow{3}{*}{ Treatment } & \multicolumn{2}{|c|}{ Dry Weight } & \multirow{3}{*}{$\begin{array}{c}\text { Weight Gain } \\
(\%)\end{array}$} \\
\hline & \multicolumn{2}{|c|}{ Days } & \\
\hline & 0 & 30 & \\
\hline L0T1 & 35,00 & 73.20 & 109,10 \\
\hline LOT2 & 29,00 & 56,10 & 93,40 \\
\hline L0T3 & 22,50 & 39,20 & 74,20 \\
\hline L1T1 & 35,00 & 45,80 & 30,90 \\
\hline L1T2 & 29,00 & 51,20 & 76,60 \\
\hline L1T3 & 22,50 & 38,80 & 72,40 \\
\hline L2T1 & 35,00 & 30,30 & 13,40 \\
\hline L2T2 & 29,00 & 29,10 & 0,30 \\
\hline L2T3 & 22,50 & 29,10 & 29,30 \\
\hline
\end{tabular}

\section{CONCLUSIONS}

The three test plants can be used for the phytoremediation process of tofu waste, concentration $25 \%$ with the best apu wood in reducing the pollutant waste.

\section{REFERENCES}

Archer, M.J.G and R.A. Caldwell, 2004. Response of Six Australian Plant Species to Heavy Metal Contamination at An Abandoned Mine Site. Water Air Soil Poll, 157(1-4): 257-267. 
Asmadi and Suharno. 2012. Basics of Wastewater Treatment Technology. Yogyakarta: GosyePublishing.

Cook , 1996.Aquatic and Wetland Plants of India, Oxford University Press, Oxford

Dordio, A and A.J.P. Carvalho. 2011. Phytoremediation: an Option for Removal of Organic Xenobiotics from Water. Handbook of

Phytoremediation, page : 51-92. ISBN: 978-1-61728-753-4. 8.

Fachrurozi., MBU., Listiatie., And Syriac D, 2010. Effect of Biomass Variation of Pistia stratiotes L. Against Decrease in BOD, COD, and TSS Liquid Waste Know in KleroSleman Yogyakarta. Journal of Public Health. 4 (1), pp. 0575. Ahmad Dahlan University, Yogyakarta.

Jenie, B.S.L. 1995. "Utilization of Tofu and Tapioca Solid Wastes and Rise Brand to Produce Red Pigments by Monascus Pupureus in Tofu Liquid

Newman, L.A and C.M. Reynolds. 2004. Phytodegradation of Organic Compounds. Curr Opin Biotechnol, 15:225230. 10.

Novianto, M.P, 2012. Effect of Time and Concentration of Acetic Acid for Reduce Waste Know, Research Report S1, Engineering

Padmaningrum, RT, Aminatun T, Yuliati: Effect of Biomass of Water Jasmine (Echinodorus paleafolius) and Lotus (Nyphaea firecrest) on Phosphate, Bod, Cod, Tss, and Degree of Laundry Liquid Waste Acidity. Journal of Research of Saintik 2014, 19 (2): 64-73.

Primayekti, Rizky. 2011. Study on Decreasing Concentration of BOD, COD, TSS of Domestic Liquid Water Wastewater using UASB Reactor. UniversitasDiponegoro: Semarang

Ratnani, R.D. 2012. Combination Capabilities of Hyacinth and Active Mud to Reduce Pollution on Industrial Liquid Wastes Tofu, Momentum, 8, 1- 5.

Rido and Rudy, L. 2010. The Use of Apu Wood Plants (Pistia Stratiotes L.) to Treat Pharmaceutical Loundry Waste Water. Scientific Journal of Environmental Engineering. Vol 5 No. 2 October 2010

Singh, O.V and R.K Jain. 2003. Phytoremediation of Toxic Aromatic Pollutants from Soil. Appl Microbiol Biot, 63 : $128-135$

Syarfi A. Achmad and M. Atikalidia, 2011 "Provision of Chemical Oxygen Demand (COD) and Production of Liquid Wastewater of Palm Oil Plant With Bioprocessor AnaerobBermedia Palm Shell," in Proceedings of National Seminar on Chemical Engineering "Kejuangan" ISSN 1693 - 4393. Laboratory of Bioprocess Engineering, Department of Chemical Engineering, University of Riau

Vymazal, Jan dan Kröpfelová, Lenka. (2008). “Wastewater Treatment in Constructed Wetlands with Horizontal Sub-Surface Flow". Springer Sciene

Zimmels., Y; Kirzhner. F.A. and Malkovskaja, 2005 of Eichhornia Crassipesand Pistia Stratiotes FortreatMentofurban Sewage in Israel", Journal of Environmental Management 81, 420-428. 